\title{
PENERAPAN MODEL PEMBELAJARAN MASTERY LEARNING UNTUK MENINGKATKAN PRESTASI BELAJAR AGAMA HINDU
}

\author{
Ni Gusti Komang Latriningsih \\ SD Negeri 8 Tianyar Barat \\ E-mail : komanglatri87@gmail.com
}

\begin{abstract}
Abstrak
Tujuan penulisan penelitian tindakan kelas ini adalah untuk mengetahui apakah Penerapan Model Pembelajaran Mastery Learning untuk meningkatkan prestasi belajar Agama Hindu Kelas V SD Negeri 8 Tianyar Barat Semester II Tahun Pelajaran 2017/2018. Lokasi tempat penelitian ini di SD Negeri 8 Tianyar Barat. SD ini terletak di Banjar Dinas Kertabuana, Desa Tianyar Barat, Kecamatan Kubu, Kabupaten Karangasem. Lokasi SD ini cukup mudah dijangkau karena terletak di pinggir jalan yang menuju Desa Pakraman Muntigunung. Subjek penelitian ini adalah murid kelas V SD Negeri 8 Tianyar Barat yang berjumlah 24 orang yang terdiri dari 10 orang siswa laki-laki dan 14 orang siswa perempuan. Data dalam penelitian ini dikumpulkan dengan tes prestasi belajar. Metode analisis data adalah deskriptif. Hasil yang diperoleh dari penelitian ini penggambaran secara lengkap dapat dijabarkan sebagai berikut: hasil yang diperoleh pada awalnya 65,00 pada siklus I menjadi 72,50 dan pada siklus II menjadi 82,00 . Hasil tersebut setelah dilakukan analisis menggunakan analisis deskriptif diperoleh kesimpulan bahwa Penerapan Model Pembelajaran Mastery Learning untuk meningkatkan prestasi belajar Agama Hindu siswa Kelas V Sekolah Dasar Negeri 8 Tianyar Barat Semester II Tahun Pelajaran 2017/2018.
\end{abstract}

Kata Kunci: Prestasi belajar, Model Pembelajaran Mastery Learning.

\begin{abstract}
The purpose of writing this class action research is to find out whether the Application of the Mastery Learning Model to improve the learning achievement of Hindu Religion Class V SD Negeri 8 Tianyar Barat Semester II Academic Year 2017/2018. The location of this research site is SD Negeri 8 Tianyar Barat. This elementary school is located in Banjar Dinas Kertabuana, West Tianyar Village, Kubu District, Karangasem Regency. The location of this elementary school is quite easy to reach because it is located on the side of the road that leads to Pakraman Muntigunung Village. The subjects of this study were 24 grade $V$ students of SD Negeri 8 Tianyar Barat, consisting of 10 male students and 14 female students. Data in this study were collected by learning achievement tests. The data analysis method is descriptive. The results obtained from this study can be described as complete as follows: the results obtained were initially 65.00 in cycle I to 72.50 and in cycle II to 82.00. These results after an analysis using descriptive analysis concluded that the application of the Mastery Learning Model to improve the learning achievement of Hindu Religion students in Class V of Elementary School 8 Tianyar Barat Semester II Academic Year 2017/2018.
\end{abstract}

Keywords: Learning achievement, Mastery Learning Learning Model 


\section{PENDAHULUAN}

Pendidikan memegang peranan penting dalam rangka mengisi pembangunan. Pembangunan di bidang SDM sangat diperlukan untuk menciptakan sumber daya manusia yang memiliki keterampilan, moral, budi pekerti serta cerdas dan kreatif. Jika memiliki sumber daya manusia yang unggul maka kita dapat bersaing dan berkompetisi dengan bangsa-bangsa lain di dunia. Keberhasilan di bidang pendidikan akan menunjang pembangunan di bidang-bidang lainnya, termasuk bidang sosial, politik, dan ekonomi. Dengan memiliki generasi penerus yang berpendidikan, bangsa ini akan semakin maju kedepannya. Mengingat pentingnya pendidikan bagi bangsa kita maka pemerintah Indonesia selalu mengupayakan hal yang terbaik untuk meningkatkan kualitas pendidikannya, mulai dari mengadakan pembaharuan kurikulum, memperbaiki sarana dan prasarana sekolah, serta mengadakan berbagai pelatihan bagi guru. Hal ini bertujuan agar tujuan pendidikan nasional dapat tercapai secara maksimal.

Adapun tujuan pendidikan nasional yang ingin dicapai sesuai dengan UU Sisdiknas Bab I pasal 3 adalah untuk mengembangkan potensi peserta didik agar menjadi manusia yang beriman dan bertaqwa kepada Tuhan Yang Maha Esa, berakhlak mulia, sehat, berilmu, cakap, kreatif mandiri, dan menjadi warga negara yang demokratis serta bertanggung jawab. Ini berarti bahwa pendidikan diharapkan untuk menciptakan anak didik yang memiliki kecerdasan dalam bidang kognitif, afektif dan juga psikomotor. Anak yang cerdas dalam hal ilmu pengetahuan haruslah memiliki budi pekerti yang baik agar mereka dapat mengaplikasikan ilmunya dengan benar.

Pendidikan Agama Hindu merupakan bagian dari struktur kurikulum muatan pendidikan nasional adalah usaha yang dilakukan secara terencana dan berkesinambungan dalam rangka mengembangkan kemampuan peserta didik untuk memperteguh keimanan dan ketaqwaan kepada Tuhan Yang Maha Esa dan berakhlak mulia, serta peningkatan potensi spiritual sesuai dengan ajaran Agama Hindu. Pendidikan Agama Hindu idealnya mampu mengembangkan potensi anak didik berbasis tujuh kecerdasan untuk membentuk perilaku yang didasari motivasi tinggi, kompetensi, pemaknaan, dan fakta dalam menjalankan tiga kerangka dasar Agama Hindu (Upacara, Susila, Filsafat). Perkembangan selanjutnya pendidikan Agama Hindu diharapkan berkemampuan melakukan penyesuaikan sikap pada domain yang benar. Agama Hindu merupakan salah satu mata pelajaran yang dapat membentuk warga menjadi lebih cerdas, terampil, dan memiliki karakter yang dilandasi oleh norma-norma Pancasila. Pendidikan Agama Hindu sangat perlu diajarkan mulai dari pendidikan anak usia dini hingga pendidikan tinggi.

Mengingat pentingnya pendidikan bagi warga negara Indonesia khususnya pendidikan Agama Hindu maka seorang guru dituntut untuk mampu merancang pembelajaran di kelas secara kreatif dan inovatif. Model pembelajaran yang tepat digunakan untuk dapat meningkatkan keaktifan siswa sehingga siswa menganggap bahwa pembelajaran Agama Hindu tidak membosankan. Kalaupun guru melibatkan siswa dalam proses pembelajaran yang berlangsung, namun hanya sebagian kecil siswa yang berpartisipasi dan biasanya didominasi oleh siswa yang pandai saja.

Menyadari kondisi yang ada, yang tentunya banyak berpengaruh terhadap kemauan guru untuk memberikan pengetahuan yang terbaik bagi setiap siswa, termasuk kemauan guru itu sendiri untuk menyiapkan bahan yang lebih baik, menerapkan metode-metode ajar yang efektif banyak berdampak pada belum tercapainya tingkat ketuntasan belajar siswa secara individual. 
Bertolak dari kesadaran tersebut, guru berkeinginan untuk memperbaiki kondisi yang ada agar tingkat perkembangan kemampuan peserta didik tidak mengalami gangguan pada tahapan berikutnya. Langkah pertama yang ditempuh adalah melakukan repleksi awal. Dari refleksi ini diperoleh kenyataan hasil prestasi belajar siswa kelas V di semester II Tahun Pelajaran 2017/2018 baru mencapai nilai 65,00. Hasil yang didapat disadari sepenuhnya masih sangat jauh dari ketetapan standar minimal pencapaian mutu pendidikan yang ditetapkan.

Upaya memperbaiki sangat perlu kiranya dilakukan, langkah perbaikan pembelajaran dengan menggunakan model pembelajaran mastery learning menjadi pilihan utama jika diperhatikan dari gambaran di atas. Karena model mastery learning berpijak pada dasar pemikiran bahwa dengan belajar tuntas (mastery learning) dapat memberikan efek meningkatkan prestasi belajar intrinsik. Model ini mengakui dan mengakomodasi semua siswa yang mempunyai berbagai tingkat kemampuan, minat dan bakat asal diberikan kondisi-kondisi belajar yang sesuai, peneliti berkeinginan untuk menerapkannya dalam pembelajaran sebagai solusi dalam mengatasi masalah prestasi belajar Agama Siswa Kelas V di SD Negeri 8 Tianyar Barat Semester II akibat ketidaksamaan perlakuan yang diberikan kepada masing-masing siswa.

Keberhasilan model pembelajaran ini juga didukung oleh beberapa penelitian lainnya. Danis Zulisyanto. 2017. Dalam penelitiannya yang berjudul "penerapan model belajar tuntas dalam upaya meningkatkan prestasi belajar siswa Kelas III MI Roudlotul Huda Sekaran kecamatan Gunungpati, Semarang pada semester genap tahun pelajaran 2016/2017, menyimpulkan bahwa pembelajaran dengan menerapkan model pembelajaran tuntas (mastery learning) dalam meningkatkan prestasi belajar siswa Kelas III pada mata pelajaran matematika telah berhasil karena telah tuntas.(Jurnal Profesi Keguruan e-ISSN 2528-7214, Vol.4 no 1 tahun 2018).

Yunita Rahmawati (2013) dalam penelitianya yang berjudul "Penerapan Metode Belajar Tuntas (Mastery Learning) Dalam Meningkatkan Hasil Belajar IPA Pada Siswa Kelas V Sd Negeri Pajang III Laweyan Surakarta" menunjukkan bahwa adanya peningkatan hasil belajar siswa. Hasil ini dapat dilihat dari presentase keberhasilan belajar siswa yang mendapat nilai lebih dari sama dengan 70, yaitu sebelum tindakan sebanyak 56,09\% (23 siswa), siklus I sebanyak 65,85\% (27 siswa), dan siklus II sebanyak 87,80\% (36 siswa). Serta dapat dilihat dari adanya peningkatan nilai rata-rata kelas, yaitu sebelum tindakan 72,90 meningkat menjadi 75,73 pada siklus I, dan meningkat lagi menjadi 80,31 pada siklus II. (Yunita Rahmawati (2013) .Skripsi: Universitas Muhamadiyah Surakarta)

Rini Astuti (2012) dengan penelitiannya yang berjudul "Penerapan metode pembelajaran Mastery Learning dapat meningkatkan keterampilan mengarang pada siswa kelas IV SD Negeri Sambirejo 4 Kecamatan Sambirejo Kota Sragen Tahun Pelajaran 2011/2012" menyimpulkan bahwa penerapan metode pembelajaran Mastery Learning dapat meningkatkan keterampilan mengarang sederhana siswa kelas IV SD Negeri Sambirejo 4 tahun pelajaran 2011/2012. Hal ini terbukti dengan Hasil penelitian menunjukkan adanya peningkatan keterampilan menulis. Hal ini dapat dilihat dari kondisi awal $53,84 \%$ mengalami peningkatan pada siklus I sebesar 76,92\% dan siklus II sebesar 100\%. (Rini Astuti.2012. skripsi: Universitas Muhammadiyah Surakarta)

\section{METODE}

Penelitian ini termasuk penelitian tindakan kelas yang direncanakan akan berlangsung selama 2 siklus, dimana setiap siklusnya terdiri dari tiga kali pelaksanaan tindakan. Dalam melaksanakan penelitian tindakan, rencana penelitian mengikuti rancangan 
yang telah diujicobakan terlebih dahulu oleh para ahli. Dalam penelitian ini, penulis memilih rancangan penelitian tindakan kelas yang disampaikan oleh Arikunto

Lokasi tempat penelitian ini di SD Negeri 8 Tianyar Barat. SD ini terletak di Banjar Dinas Kertabuana, Desa Tianyar Barat, Kecamatan Kubu, Kabupaten Karangasem. Lokasi SD ini cukup mudah dijangkau karena terletak di pinggir jalan yang menuju Desa Pakraman Muntigunung. Yang menjadi Subjek Penelitian ini adalah semua siswa kelas V SD Negeri 8 Tianyar Barat yang berjumlah 24 orang. Yang menjadi objek penelitian ini adalah peningkatan prestasi belajar Agama Hindu siswa kelas V SD Negeri 8 Tianyar Barat setelah diterapkan pemberian tugas dalam kerja kelompok menggunakan model mastery learning dalam proses pembelajaran. Penelitian ini dilakukan dari bulan Januari sampai bulan Mei 2018

Kriteria keberhasilan pelaksanaan penelitian ini berpedoman pada kriteria sebagai berikut. Siswa dinyatakan tuntas jika sudah mampu memperoleh nilai Kriteria Ketuntasan Minimal (KKM) belajar secara individu yaitu 75. Secara klasikal, siswa dinyatakan tuntas apabila $75 \%$ dari jumlah siswa keseluruhan yang ada di kelas memperoleh nilai 75 ke atas.

Apabila indikator keberhasilan pada pencapaian penguasaan materi sudah tercapai maka penelitian dihentikan dan akan dijadikan pembahasan dan simpulan bahwa siklus tersebut telah tercapai.

\section{HASIL DAN PEMBAHASAN}

Berdasarkan analisis data yang dilakukan pada hasil refleksi awal menunjukan bahwa rata-rata hasil belajar Agama Hindu siswa belum sesuai dengan harapan yaitu belum mencapai KKM yaitu 75. Hal tersebut dapat dilihat dari rata-rata yang diperoleh oleh siswa mencapai 65 dan ketuntasan belajar siswa mencapai 33\%, sehingga dipandang perlu melakukan perbaikan kegiatan pembelajaran guna meningkatkan hasil belajar siswa Kelas $\mathrm{V}$ SD Negeri 8 Tianyar Barat.

Setelah dilakukan tindakan pada siklus I dan siklus II didapatkan hasil pada table di bawah ini.

Tabel Rekapitulasi Hasil Penelitian dari Siklus I - Siklus II

\begin{tabular}{|c|c|c|c|c|c|c|c|}
\hline Variabel & $\begin{array}{l}\text { Rata- } \\
\text { rata } \\
\text { Awal }\end{array}$ & $\begin{array}{l}\text { Siklus } \\
\text { Rata- } \\
\text { rata }\end{array}$ & $\begin{array}{l}\text { Kenaikan } \\
\text { Nilai }\end{array}$ & $\begin{array}{l}\text { Prosentase } \\
\text { Kenaikan }\end{array}$ & $\begin{array}{l}\text { Siklus } \\
\text { Rata- } \\
\text { rata }\end{array}$ & $\begin{array}{l}\text { s II } \\
\text { Kenaikan } \\
\text { Nilai }\end{array}$ & $\begin{array}{l}\text { Prosentase } \\
\text { Kenaikan }\end{array}$ \\
\hline 1 & 65,00 & 72,50 & 7.50 & 10,34 & 82,00 & 9,50 & 11.58 \\
\hline
\end{tabular}

\section{Pembahasan Hasil Yang Diperoleh Siklus I}

Hasil tes prestasi belajar yang merupakan tes isian dan menjawab singkat mengupayakan siswa untuk betul-betul dapat memahami apa yang sudah dipelajari. Nilai rata-rata siswa di siklus I sebesar 72,50 menunjukkan bahwa siswa setelah menguasai materi yang diajarkan walaupun belum begitu sempurna. Hasil ini menunjukkan peningkatan kemampuan siswa dari awal ke siklus I.

Hasil tes prestasi belajar di Siklus I telah menemukan efek utama bahwa penggunaan metode Mastery Learning akan berpengaruh terhadap prestasi belajar siswa yang dalam hal ini adalah model pembelajaran Mastery Learning. Hal ini sesuai dengan hasil meta analisis model pembelajaran yang dilakukan oleh Soedomo (dalam Puger, 2004) yang menyatakan 
bahwa metode pembelajaran yang diterapkan oleh seorang guru berpengaruh terhadap prestasi belajarnya.

Seperti telah diketahui bersama bahwasannya Model Pembelajaran Mastery Learning menitik beratkan pembelajaran pada aspek kognitif, sebagai pedoman prilaku kehidupan sehari-haris siswa. Untuk penyelesaian kesulitan yang ada maka penggunaan model ini dapat membantu siswa untuk berkreasi, bertindak aktif, bertukar pikiran, mengeluarkan pendapat, bertanya, berdiskusi, berargumentasi, bertukar informasi dan memecahkan masalah kehidupan yang nanti efek selanjutnya adalah para siswa akan dapat memahami dan meresapi mata pelajaran Agama Hindu lebih jauh.

Kendala yang masih tersisa yang perlu dibahas adalah prestasi belajar yang dicapai pada siklus I ini belum memenuhi harapan sesuai dengan kriteria keberhasilan penelitian yang diusulkan di sekolah ini yaitu 75. Oleh karenanya upaya perbaikan lebih lanjut masih perlu upayakan sehingga perlu dilakukan perencanaan yang lebih matang untuk siklus selanjutnya.

\section{Pembahasan Hasil Yang Diperoleh Siklus II}

Hasil yang diperoleh dari tes prestasi belajar di siklus II menunjukkan bahwa kemampuan siswa dalam mengikuti pelajaran sudah baik. Ini terbukti dari rata-rata nilai siswa mencapai 82. Hasil ini menunjukkan bahwa Model Pembelajaran Mastery Learning telah berhasil meningkatkan kemampuan siswa menempa ilmu sesuai harapan. Model Pembelajaran Mastery Learning merupakan model yang cocok bagi siswa apabila guru menginginkan mereka memiliki kemampuan berkreasi, berbicara banyak, mengeluarkan pendapat secara lugas, berpikir logis, menganalisis, mengingat penggunaan metode ini adalah untuk memupuk kemampuan berbicara siswa, rasa ingin tahu siswa, kemampuan lebih untuk berprestasi, memupuk kesenangan yang dinggi dalam belajar, mengupayakan kemampuan yang tinggi untuk siswa dapat berinteraksi dengan materi, berinteraksi dengan sesama siswa dan juga dengan guru.

Hasil penelitian ini ternyata telah memberi efek utama bahwa model yang diterapkan dalam proses pembelajaran berpengaruh secara signifikan terhadap prestasi belajar siswa. Temuan ini membuktikan bahwa guru sudah dapat memilih metode dalam melaksanakan proses pembelajaran karena pemilihan metode merupakan hal yang tidak boleh dikesampingkan. Hal ini sejalan pula dengan temuan-yemuan peneliti lain seperti yang dilakukan oleh Inten (2004) dan Puger (2004) yang pada dasarnya menyatakan bahwa metode pembelajaran yang diterapkan berpengaruh terhadap prestasi belajar siswa.

Beberapa mata pelajaran yang digabungkan mengupayakan pembelajaran yang menitik beratkan kajiannya pada aspek kognitif, sebagai pedoman atas kemampuan siswa baik pikiran, prilaku maupun keterampilan yang dimiliki. Untuk semua bantuan terhadap hal ini, Model Pembelajaran Mastery Learning menempati tempat yang penting karena dapat mengaktifkan siswa secara maksimal. Dari nilai yang diperoleh siswa pada siklus I, 7 siswa mendapat nilai di atas KKM, 3 siswa memperoleh nilai sesuai KKM dan 14 siswa memperoleh nilai di bawah KKM. Sedangkan nilai yang diperoleh siswa pada siklus II,17 siswa mendapat nilai di atas KKM, 6 siswa memperoleh nilai sesuai KKM dan 1 siswa memperoleh nilai di bawah KKM. Dari perbandingan nilai ini sudah dapat diyakini bahwa prestasi belajar siswa dapat ditingkatkan dengan penggunaan Model Pembelajaran Mastery Learning. Walaupun penelitian ini sudah bisa dikatakan berhasil, namun pada saat-saat peneliti mengajar di kelas selanjutnya, cara ini akan terus dipraktekkan.

Setelah dibandingkan nilai awal, nilai siklus I dan nilai siklus II, terjadi kenaikan yang signifikan, yaitu dari rata-rata nilai awal adalah 65,00 naik di siklus I menjadi 72,50 dan di 
siklus II naik menjadi 82,00. Kenaikan ini tidak bisa dipandang sebelah mata karena kenaikan nilai ini adalah upaya-upaya yang maksimal yang dilaksanakan peneliti demi peningkatan mutu pendidikan dan kemajuan pendidikan khususnya di SD Negeri 8 Tianyar Barat.

\section{SIMPULAN DAN SARAN}

Penerapan Model Pembelajaran Mastery Learning dalam penelitian ini, keberhasilannya dapat dibuktikan dengan data sebagai berikut : (1) Dari data awal ada 18 siswa mendapatkan nilai di bawah KKM dan pada siklus I menurun menjadi 14 siswa dan siklus II hanya 1 siswa mendapat nilai di bawah KKM. (2) Nilai rata-rata awal 65,00 naik menjadi 72,50 pada siklus I dan siklus II naik menjadi 82,00. (3) Dari data awal siswa tuntas hanya 6 orang sedangkan pada siklus I menjadi lebih banyak yaitu 10 siswa dan pada siklus II menjadi cukup banyak yaitu 23 siswa..

Dari semua data pendukung pembuktian pencapaian tujuan pembelajaran dapat disimpulkan bahwa Model Pembelajaran Mastery Learning dapat memberi jawaban yang diharapkan sesuai tujuan penelitian ini.

Sehubungan dengan keberhasilan penelitian yang telah dilaksanakan, maka saran yang dapat disampaikan adalah sebagai berikut : (1) Dalam melaksanakan proses pembelajaran pada mata pelajaran Agama Hindu, penggunaan Model Pembelajaran Mastery Learning semestinya menjadi pilihan dari beberapa metode yang ada mengingat model ini telah terbukti dapat meningkatkan kerjasama, berkreasi, bertindak aktif, bertukar informasi, mengeluarkan pendapat, bertanya, berdiskusi berargumentasi dan lain-lain. (2) Walaupun penelitian ini sudah dapat membuktikan efek utama dari Model Pembelajaran Mastery Learning dalam meningkatkan aktivitas dan prestasi belajar, sudah pasti dalam penelitian ini masih ada hal-hal yang belum sempurna dilakukan, oleh karenanya kepada peneliti lain yang berminat meneliti topik yang sama untuk meneliti bagian-bagian yang tidak sempat diteliti. (3) Penelitian lanjutan guna verifikasi data hasil penelitian ini perlu dilakukan sebagai penguatan, diharapkan bagi peneliti lain yang berkeinginan untuk melakukan penelitian menyangkut Pembelajaran Tuntas agar mencari bidang yang belum sempat peneliti tuntaskan. .

\section{DAFTA RUJUKAN}

Arikunto, Suharsimi; Suhardjono; Supardi. 2006. Penelitian Tindakan Kelas. Jakarta: PT Bumi Aksara.

Bandung, 2008

Danis Zulisyanto. 2017. Dalam penelitiannya yang berjudul "Penerapan Model Belajar Tuntas Dalam Upaya Meningkatkan Prestasi Belajar Siswa Kelas III MI Roudlotul Huda Sekaran Kecamatan Gunungpati, Semarang Pada Semester Genap Tahun Pelajaran 2016/2017.

Depdikbud. 1994. Petunjuk Pelaksanaan Proses Belajar Mengajar. Jakarta: Direktorat Pendidikan Menengah Umum.

Djamarah, Syaful Bahri. 2002. Prestasi Belajar dan Kompetensi Guru. Surabaya: Usaha Nasional. 
Hanif Nurcholis, DR. Msi. Gambaran Guru Profesional.. Postingan Supiyadi.

Inten, I Gede. 2004. Pengaruh Model Pembelajaran dan Pengetahuan Awal Siswa Terhadap Prestasi Belajar PKn dan Sejarah pada Siswa Kelas II di SMU Laboratorium IKIP Negeri Singaraja. Tesis. Program Pascasarjana IKIP Negeri Singaraja.

Kunandar, Guru Profesional, (Jakarta; Rajawali Pers,2007).

Nana Sudjana, Penilaian Hasil Proses Belajar Mengajar, Remaja Rosdakarya,

Nana Syaodih Sukmadinata. 2005. Metode Penelitian Pendidikan. Bandung: Remaja Rosda Karya.

Peraturan Menteri Pendidikan Nasional No. 41 Tahun 2007 Tanggal 23 November 2007. Jakarta: Depdiknas.

Puger, I Gusti Ngurah. 2004. Pengaruh Model Pembelajaran dan Kemampuan Berpikir Silogisme Terhadap Prestasi Belajar Biologi Pada Siswa Kelas III SMP Negeri Seririt (Experimen Pada Pokok Bahasan Reproduksi Generatif Tumbuhan Angiospermae). Tesis. Singaraja: IKIP Negeri Singaraja.

Rini Astuti (2012). Dengan Penelitiannya Yang Berjudul "Penerapan Metode Pembelajaran Mastery Learning Dapat Meningkatkan Keterampilan Mengarang Pada Siswa Kelas IV SD Negeri Sambirejo 4 Kecamatan Sambirejo Kota Sragen Tahun Pelajaran 2011/2012.

Sardiman, A.M. 1988. Interaksi dan Motivasi Belajar-Mengajar Pedoman bagi Guru dan Calon Guru. Jakarta: Rajawali Pers.

Slamet, PH. 2004. MBS, Life Skill, KBK, CTL dan Saling Keterkaitannya.Makalah yang Disampaikan pada Semiloka DBEP di NTB dan Bali.

Soedomo, M.2001. Landasan Pendidikan. Malang: Penyelenggaraan Pendidikan Pascasarjana Proyek Peningkatan Perguruan Tinggi.

Sudjana. 1996. Metoda Statistika. Bandung: Tarsito.

Sukmadinata \& Nana Syaodih. (2005). Landasan Psikologi Proses Pendidikan. PT. Remaja Rosdakarya: Jakarta.

Wardani, I. G. A. K Siti Julaeha. Modul IDIK 4307. Pementapan Kemampuan Mengajar. Jakarta : Universitas Terbuka.

Yunita Rahmawati (2013). Dalam Penelitianya Yang Berjudul "Penerapan Metode Belajar Tuntas (Mastery Learning) Dalam Meningkatkan Hasil Belajar IPA Pada Siswa Kelas V SD Negeri Pajang III Laweyan Surakarta. 